\title{
KELELAWAR SEBAGAI SUMBER INSPIRASI DALAM PENCIPTAAN SENI TEKSTIL
}

\author{
Arief Satriyo Wibowo $*$ )
}

\begin{abstract}
Bats are flying mammals, now these animals have several species of bats that are endangered. Due to the destruction of the original habitat of the bark in the forest that becomes the function, the exploitation of karst areas (lime), the use of pesticides on agricultural land, hunting and excessive consumption. Many functions of bat ecology therefore in need of efforts in controlling the population of bats. The idea of the creation of this textile artwork originated from personal experience, natural factors, sympathy and empathy for the preservation of fauna, namely bat animals. All of which are then transformed into non-functional work forms which furthermore want to bring the values of change so that the celebration can know it and finally feels may be able to understand the message delivered. The process of creating works on non functional techniques used in the form of nylon nylon thread wire on top of the wire.
\end{abstract}

Keywords: bats, non-functional, creation textiles

\begin{abstract}
ABSTRAK
Kelelawar merupakan hewan mamalia terbang, sekarang hewan ini terdapat beberapa spesies kelelawar yang statusnya terancam punah. Akibat rusaknya habitat asli kelalawar di hutan yang menjadi alih fungsi, eksploitasi wilayah karst (kapur), penggunaan pestisida pada lahan pertanian, perburuan serta pengkonsumsian yang berlebihan. Banyak fungsi ekologi kelelawar oleh karena itu di perlukan usaha-usaha dalam mengendalikan populasi kelelawar. Ide penciptaan karya seni tekstil ini berawal dari pengalaman pribadi, faktor alam, rasa simpati dan empati terhadap kelestarian fauna yaitu hewan kelelawar. Kesemua yang kemudian ditransformasikan ke bentuk karya non fungsional yang selanjutnya ingin membawa nilai-nilai perubahan sehingga khlayakan dapat mengetahuinya dan akhirnya dirasa mungkin dapat mengerti akan pesan yang disampaikan. Proses penciptaan karya pada non fungsional tehnik yang digunakan berupa lilit benang nilon hank di atas kawat.
\end{abstract}

Kata kunci: kelelawar, non fungsional, penciptaan tekstil

PENDAHULUAN

Beragam tumbuhan dan satwa

bisa tumbuh dan mendiami wilayah

di Indonesia. Ciri khas atau pun keunikannya serta memiliki fungsi dari masing-masing dari yang langka pun menjadikan sesuatu yang istimewa pula namun kekhawatiran sudah pasti ada

*Arief Satriyo Wibowo, email: arief_satriyo31@gmail.com, Mahasiswa Pasca Sarjana Institut Seni Indonesia Yogyakarta 
yaitu yang langka yang terancam punah. Dari ragam satwa yang langka setidaknya Elang Jawa, Harimau Sumatera, Gajah Sumatera, Badak Jawa berada dalam keadaan terancam punah. Sejatinya juga ada beberapa spesies kelelawar yang statusnya juga terancam punah.

\section{Kepala Pusat Penelitian Biologi} LIPI, Siti Nurmalianti Priyono membenarkan kelelawar terancam punah. "Akibat rusaknya habitat asli kelalawar di hutan yang menjadi alih fungsi, eksploitasi wilayah karst (kapur), penggunaan pestisida pada lahan pertanian, perburuan serta pengkonsumsian yang berlebihan. populasinya terus berkurang, bahkan beberapa jenis telah punah".

Beberapa media cetak maupun elektronik di Indonesia telah melaporkan bahwa pada beberapa tempat di Jawa Timur, Jawa Barat, dan Yogyakarta, daging kelelawar diolah menjadi abon untuk dikonsumsi dan diperdagangkan, hal tersebut karena masyarakat meyakini bahwa, selain sebagai bahan pangan, daging kelelawar juga dapat menyembuhkan penyakit. Untuk masyarakat Sulawesi, jenis kelelawar pemakan buah sudah dijadikan sebagai bahan makanan alternatif sumber protein hewani, sehingga di pasar-pasar tradisional maupun swalayan sering dijumpai kelelawar sebagai salah satu produk yang ditawarkan.

Beragam manfaat yang diberikan oleh hewan mamalia terbang ini, berfungsi sebagai predator alami hama pertanian, terdapat 186 jenis tumbuhan tropis yang bergantung pada penyerbukan benih yang dilakukan kelelawar, penyerbukan bunga, alat pengontrol biologi penyakit malaria, arthopods penyebar penyakit ternak serta hama tikus, peran kunci dalam menjaga populasi serangga "dalam 1 jam bisa memakan 600 serangga" sehingga nantinya dapat menghemat berapa persen pengeluaran pada pestisida, bahkan ada sejumlah buah yang proses reproduksinya bergantung pada kelelawar, dan dalam dunia teknologi kelelawar menjadi sumber inspirasi berbagai hal.

Banyak fungsi ekologi kelelawar oleh karena itu di perlukan usaha-usaha dalam mengendalikan populasi kelelawar. kita tidak tahu tentang perubahan alam ini, perubahan secara alami ataupun yang sengaja akibat ulah manusia yang nantinya membahayakan ekosistem kelelawar. Mengingat pada karya seni juga sebuah komunikasi yang dapat membangkitkan persepsi penikmat, sehingga memberikan suatu maksud, suatu inspirasi, dan harapan bagi umat manusia untuk membuka jalan menjalani hidup yang lebih baik. Akumulasi pengalaman dan perasaan yang diramu menjadi sebuah gagasan, Ide atau gagasan tersebut di transformasikan ke dalam bentuk-bentuk simbolik.

Setelah mengetahui kondisi ada beberapa jenis kelelawar yang terancam punah di Indonesia pada masa ini penulis ingin menunjukkan rasa empati dan mengangkat hal ini menjadi ide dalam berkarya seni. Dalam karya yang berjudul "Kelelawar sebagai Sumber Inspirasi dalam Penciptaan Seni Tekstil" membuat karya dengan menggunakan bahan baku utama berupa benang nilon hank. Karakteristik benang yang di padukan dengan objek kelelawar menampilkan satu karakter dan nilai estetik tersendiri terhadap karya seni. Oleh karena itu dapat dirumuskan dengan 
masalah bagaimana bentuk dan wujud kelelawar dan bagaimana mewujudkan bentuk kelelawar dalam karya seni kriya tekstil yang artistik?

\section{METODE}

Penting juga penggunaan metode penciptaan yang dipakai dalam pengumpulan data dilapangan/observasi ataupun studi yang lainnya untuk mendukung terciptanya kelancaran proses penciptaan karya seni (Gustami, 2007:329). Lahirnya sebuah karya seni tentu bukan lahir begitu saja, akan tetapi mengalami proses yang tersistematis. Proses dalam pembuatan karya secara tersusun akan memudahkan pengkarya dalam menciptakannya. Kematangan konsep yang dirancang pasti dalam proses pengolahan akan mengalami perubahan, untuk menambah nilai keindahan ataupun menutupi suatu kesalahan yang terjadi. Perubahan itu wajar asalkan tidak mengalami perubahan secara keseluruhan baik dari segi wujud, isi maupun dari konsep dari rancangan karya tersebut.

Menurut Gustami (2007:329), melahirkan sebuah karya seni khususnya seni kriya secara metodologis melalui tiga tahapan utama, yaitu Eksplorasi (pencarian sumber ide, konsep, dan landasan penciptaan), Perancangan (rancangan desain karya) dan Perwujudan (pembuatan karya). Eksplorasi meliputi langkah pengembaraan jiwa dan penjelajahan dalam menggali sumber ide. Tahap perancangan terdiri dari kegiatan menuangkan ide dari hasil analisis yang telah dilakukan ke dalam bentuk dua dimensional atau disain. Tahap perwujudan merupakan tahap mewujudkan ide, konsep, landasan, dan rancangan menjadi karya. Dari semua tahapan dan langkah yang telah dilakukan perlu dilakukan evaluasi untuk mengetahui secara menyeluruh terhadap kesesuaian antara gagasan dengan karya diciptakan.

\section{PEMBAHASAN}

Kain pada mulanya diciptakan untuk perlindungan tubuh manusia dari gangguan alam. Dalam perkembangan peradaban, tekstil berkembang sebagai media pelengkap dalam upacara dan keseharian. Perkembangan tekstil ditemukan pula dalam segi simbolisme dan ekspresi seni. Jawaharlal Nehru, Perdana Menteri India, mengutarakan sebuah kalimat mengenai seni tekstil, "The early beginnings of civilization are tied up with the manufacture of textiles, and history might well be written with this as the leading motif." Nehru menekankan bahwa ikatan antara peradaban dan produk tekstil sangatlah erat, dalam berbagai segi. Perkembangan seni, tak terkecuali seni tekstil menunjukkan perkembangan nilai, teknologi, dan ekonomi yang ada di masyarakat (intisari, 1999:430).

Pembahasan tentang "nilai" tekstil atau kain menurut Biranul Anas memang bukan hanya soal jenis bahan atau teknik pembuatan, tapi juga fungsi dan peran sosialnya. ekspresi seni melalui medium tekstil, kain, benang, dan serat. Berkaitan dengan soal fungsi biasanya dibuat dalam bentuk berbagai alat untuk kegunanan hidup secara praktis, dalam artian mempresentasikan masa lalu, mengandung perlawanan pada gagasan perubahan dan berbagai hasilnya, serta mengandung nilai temuan dan keaslian 
(originality). Oleh karena itu dalam proses penciptaan karya seni, mengungkapkan suatu ekspresi dan makna simbolisasi dengan eksplorasi bentuk dari kelelawar beserta simbolisasi dengan maksud ingin menyampaikan suatu harapan melalui pengalaman pribadi.

Melalui pengalaman pribadi menuntun lah pada fungsi seni pada Laura H. Chapman yang menjadi pijakan dalam berkarya, ada 2 yang menjadi pijakan yaitu fungsi pribadi (individual) dan fungsi masyarakat (social). fungsi pribadi, konsep yang lebih menekankan pada proses emosional dari sang seniman, bagi seniman juga akan tercapai kepuasan jiwa atau diri, ketika semua konsep pemikirannya telah tertuang dalam karya, sedangkan fungsi social ialah setiap karya seni yang diciptakan seniman, pada umumnya akan disajikan kepada masyarakat atau audiens, disitu karya seni dinikmati, diamati, diapresiasi sehingga timbullah proses komunikasi.

Pengkarya berharap karya yang akan diciptakan nantinya mampu menjadi sarana komunikasi antara pengkarya dan penikmat, seperti yang disampaikan oleh Gustami SP bahwa: "karya seni yang hidup karya seni yang memiliki kekuatan berdialog dengan penikmatnya, bisa membangkitkan komunikasi. Tanpa dialog seni tidak dapat bercerita pada penikmatnya, kehadiranya sering tidak berfungsi. Maka dalam penciptaan karya seni kriya tekstil ini penulis memilih pendekatan bentuk, fungsi, dan ekspresi.

Bahan merupakan hal terpenting untuk menentukan hasil akhir dalam pembuatan karya, bahan berkualitas baik dapat menentukan pencapaian bentuk yang maksimal, dapat bertahan dalam waktu lama dan memberi kesan estetik yang terlihat dari segi kualitas dari bahan itu sendiri maka dipilih lah benang nilon hank. Bahan baku utama dalam pengerjaan karya seni kriya ini menggunakan benang, kawat besi, busa, dan malam. Pemilihan benang menggunakan benang nilon hank ukuran benang 18, 25, dan 30 dengan warna yang telah di tentukan sehingga dirasa dapat memunculkan warna-warna yang mengkilap atau silau dimata, untuk malam sendiri menggunakan malam yang baru dan yang bekas sebagai pendukung tekstur dalam pembentukan karya.

Nilon sendiri berasal dari serat poliamida sintetik rantai panjang di mana kurang dari $85 \%$ tautan amida melekat langsung ke dua cincin aromatik. Tingkat ergonomik dari bahan benang sendiri dapat dipertanggungjawabkan, sudah jelas selain sangat tangguh, elastisitas tinggi, sangat kuat, tahan lama karena benang tersebut berasal dari serat buatan manusia (non selulosa). Selain hal itu karakter benang yang tahan terhadap serangga, jamur, lumut serta kebusukan sehingga tepat dalam pemilihan dalam pembuatan karya. Bahan kawat digunakan untuk karya yang non fungsional atau karya alternatif sebagai kerangka dalam pelilitan dari benang, sedangkan dalam pembuatan volume menggunakan busa. Pemilihan kawat besi sesuai dengan kebutuhan yaitu mudah di bengkokan tapi kokoh serta tidak terlalu berat, pengambilan kawat besi dengan ukuran ketebalan $2 \mathrm{~mm}$ dan $4 \mathrm{~mm}$ dirasa cukup apa yang menjadi kebutuhan. Pendekatan fungsi dalam penciptaan karya seni tekstil ini adalah menciptakan karya tekstil dengan ide dan 
gagasan baru dalam bentuk distorsi dan fantasi (impian) dalam pembuatan karya kriya non fungsional. Inspirasi dari kelelawar ini dapat dipakai sebagai jembatan menuju sebuah karya yang mengekskpresikan pengalaman pribadi dan nantinya di tuju pada pesan sosial. Karya ini akan menggunakan sumber inspirasi dari karakter kelelawar dalam bentuknya, morfologi, anatomi tubuh kelelawar, dan hal-hal yang dapat berhubungan dengan tema kelelawar. Penciptaannya dengan tema baru ini akan memperkaya imajinasi dan teknik dalam pembuatan karya khususnya seni kriya tekstil yang unik dan kreatif.

Menciptakan sebuah karya seni tidak asal dalam membuatnya, untuk itu melalui pendekatan ekpresi sendiri ada dua pijakan yang dipakai, penciptaan karya ini melalui estetis yaitu metode yang digunakan mengacu pada nilai-nilai estetis yang terkandung dalam seni rupa, sehingga mempengaruhi seni tesebut seperti garis (line), bentuk (shape), warna (color), tekstur (texture) dan lain-lain (Feldman, 1967). Selain itu, untuk menuangkan fungsi masyarakat perlu pendekatan semiotika yang digunakan dalam penciptaan karya seni kriya ini adalah semiotika Charles Sanders Peirce - Pendekatan tanda yang didasarkan pada pandangan seorang filsuf dan pemikir Amerika yang cerdas, Charles Sanders Peirce (1839-1914) yaitu cara yang digunakan untuk mengetahui apakah dalam sebuah karya seni memiliki makna symbol, index, dan icon. Pendekatan ini sebenarnya dipakai sebagai pemaknaan karya atas maksud dan tujuan secara filosofis.
Seni tidak hanya hadir sebagai rangsangan estetis namun hadir dari gejolak keresahan diri yang ingin diwujudkan ataupun dibicarakan dalam sebuah karya melalui dorongan estetis dan kelengkapan teknik yang matang. Sebuah karya seni lahir dari ungkapan seorang seniman berdasarkan singgungan dirinya dengan pengalaman yang berasal dari luar dirinya. Persinggungan ini memberikan daya imajinatif sebagai ide dalam melahirkan sebuah karya. Hal ini disebut sebagai dorongan estetis yang berasal dari diri seorang seniman yang membentuk kepekaan dalam merespon objek dan material.

Dalam penciptaan ini sebuah persinggungan antara saya dan kelelawar. Esensi kelelawar adalah hewan mamalia terbang sebagai predator alami hama pertanian akan tetapi ada beberapa spesies hewan ini yang terancam punah. Hal ini memberikan daya imajinatif kepada saya untuk mengahdirkan kembali nilainilai akan pentingnya kesadaran dalam hidup bersama. Dari persinggungan ini memberikan dorongan untuk menentukan konsep dalam menciptakan karya. Dalam penciptaan ini saya sebagai pencipta karya memiliki konsep merepresentasikan karya seni sebagai media sosial dan kritik terhadap fenomena negatif yang terjadi dalam kehidupan sehari-hari.

Penciptaan karya seni bukanlah sesuatu yang instan serta tidaklah terjadi secepat apa yang kemudian kita bayangkan tetapi memerlukan tahapan-tahapan. Dalam tahap ekplorasi, seniman melakukan penggalian seputar hewan kelelawar dalam waktu perkembangan sekarang, baik itu melalui pengalaman dan 
sumber-sumber lainnya. Eksplorasi dalam pembentukan visual pada tahapan ini dilakukan dengan penggalian sumber refrensi mengenai kelelawar sebagai metafor. Fenomena kelelawar dalam kehidupan sehari-hari tidak lepas dari kejadian-kejadian yang dialami maupun disebabkan oleh manusia dalam menjalani kehidupan di dunia. Dalam hal ini eksplorasi dilakukan dengan melihat bermacam-macam bentuk kelelawar serta unsur-unsur pendukung yang ada di sekitarnya. Dari proses eksplorasi itu memunculkan beberapa simbol-simbol yang akan dipadukan dengan dengan beberapa bentuk tertentu dari tubuh kelelawar.

Tahap berikutnya, ditekankan pada eksperimen mengolah kumpulan referensi menjadi visualisasi karya sesuai tema. Proses ini dilakukan dengan melakukan percobaan-percobaan dengan sketsa. Adapun sketsa yang terpilih dalam perencanaan karya sebagai berikut:

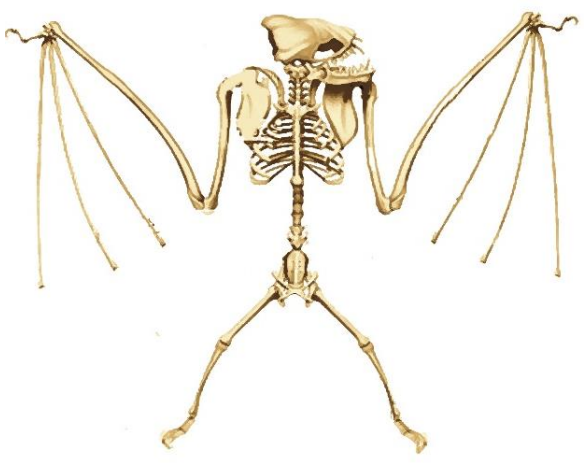

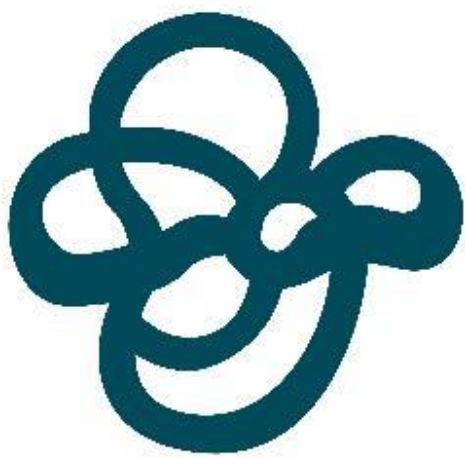

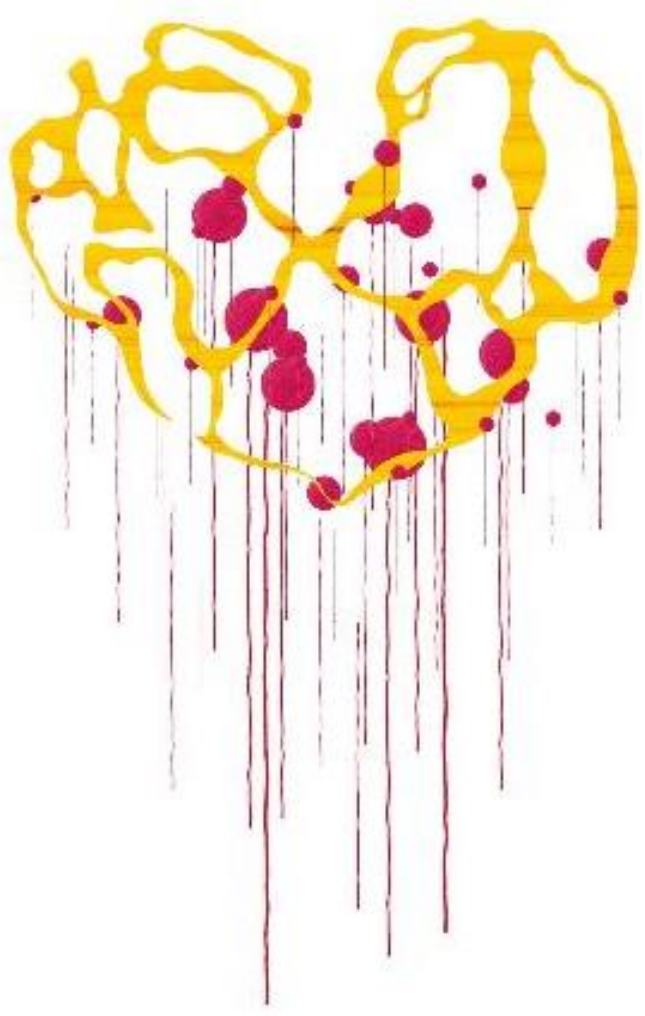

Gambar 1. Sketsa terpilih

Perwujudan karya merupakan suatu hal dimana seorang pencipta harus berusaha serta mampu mengaplikasikan latar belakang hingga konsep penciptaan dalam bentuk proses visualisasi. Ada berbagai macam langkah dalam perwujudan karya, kenyamanan dan kesesuaian alat bahan cukup besar pengaruhnya dalam peciptaan karya. Pada perwujudan karya seni kriya tugas penciptaan II ini menggunakan beberapa 
langkah yaitu pembentukan karakter pada kawat, pemberian volume pada kawat, pelilitan benang nilon hunk pada kawat, dan pemberian lem fox putih pada benang. Proses pembentukan karakter pada kawat, pembentukan dilakukan dengan tangan dan menggunakan tank, ukuran ketebalan kawat yang di perlukan 3, 6, dan 8, untuk penguncian kawat sendiri dengan teknik las. Pemberian volume pada kawat dilakukan dengan pemberian solasi bolak balik pada kawat setelah itu masukan busa yang telah di bentuk, masih ada proses selanjutnya yaitu pemberian solasi kertas dan solasi bolak balik lagi. Pemberian solasi kertas ini agar bentuk yang diinginkan dapat tercapai karena karakter busa yang mudah bengkok dan tidak rata apabila di tekan. kemudian pelilitan benang, benang harus lilit dulu pada bagian lain untuk selanjutnya baru dililitkan pada karya karena selain nantinya dapat meminimalisir waktu serta terjadinya kerumitan. Benang yang di pakai ada dua ukuran yaitu ukuran 18 dan 30 dengan warna putih tulang serta turqoise. Untuk proses pelilitan ini di perlukan tingkat kesabaran yang tinggi, dan perlu kejelian serta ketelitian dalam pengambilan pada titik-titik awal dalam pengerjaannya kalau salah dalam pengambilan nantinya akan membuat tidak rapi. Finishingnya menggunakan lem fox putih hal ini dirasa tepat selain lem fox menghantar kan kekakuan dan tidak kotor maupun berubah warna. berikut proses-proses perwujudan karya:
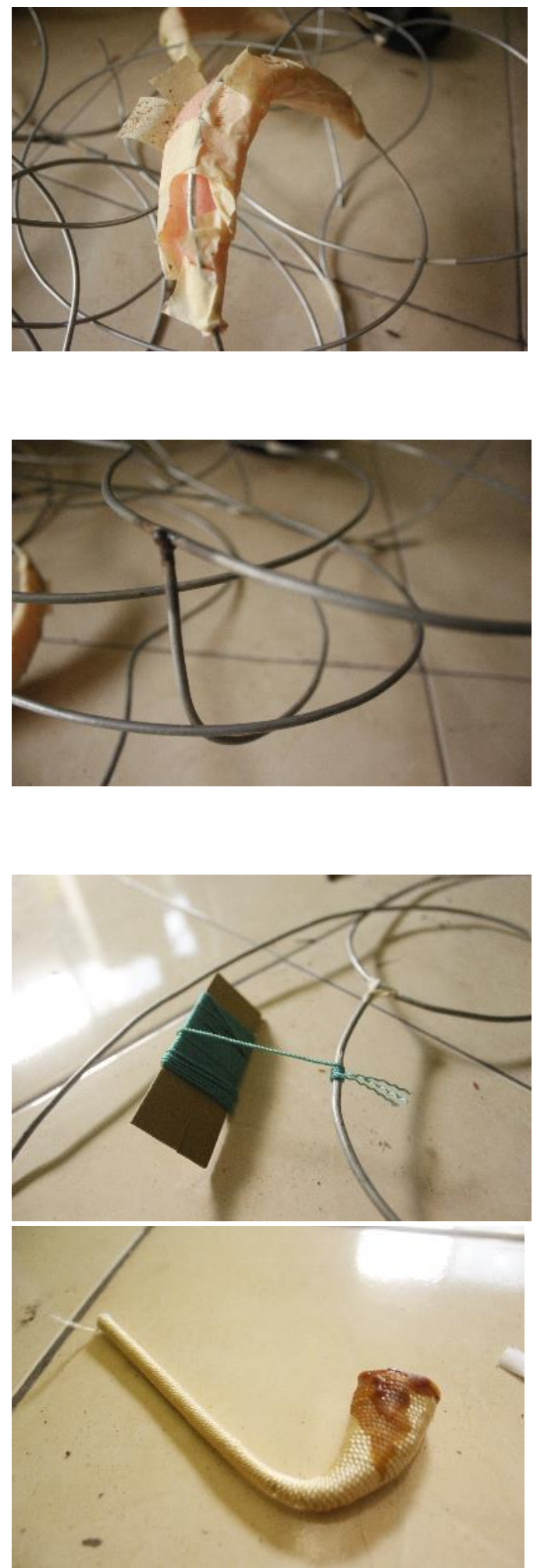

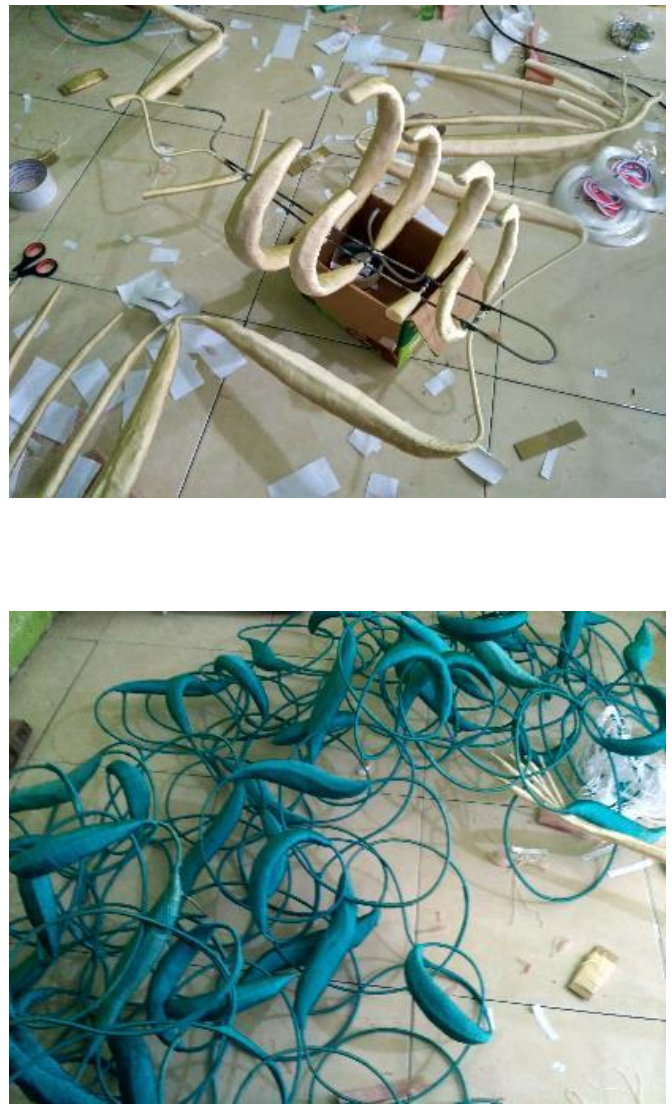

Gambar 2. Proses perwujudan

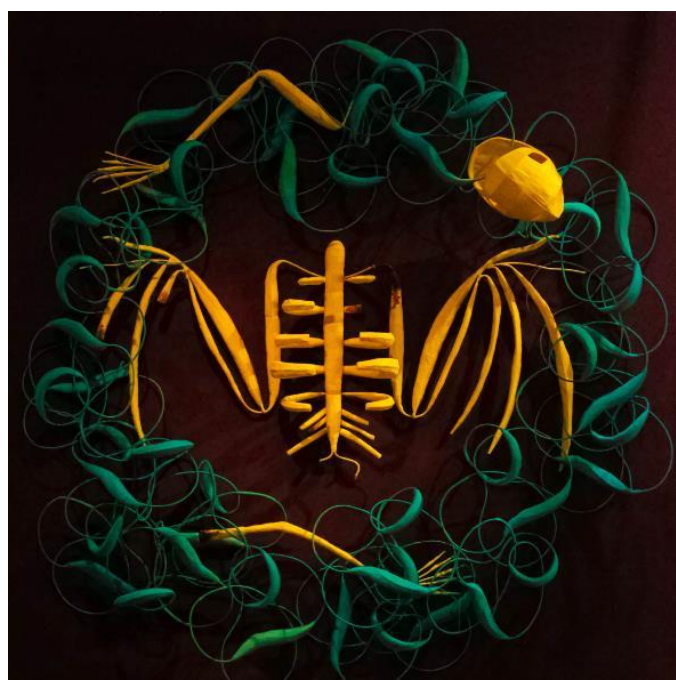

Gambar 3. Karya 1, Judul Karya "Save Me",

Ukuran : $190 \mathrm{~cm} \times 190 \mathrm{~cm}$, Teknik: lilit.

Bahan : Benang Nilon Hank

(Foto : Arief Satriyo Wibowo, 2017)
Pada karya yang berjudul "Save Me" ingin menegaskan bahwa sesungguhnya kita sebagai manusia harus mengerti atau peka terhadap lingkungan sekitar khususnya terhadap hewan kelelawar. karya ini menggambarkan rangka kelelawar yang pada bagian tertentu tidak ada, yang mengartikan kerusakan pada hewan ini sebagai pengandaian perlu adanya perawatan. selain itu, rangka warna hijau yang mengelilingi karakter utama terinspirasi dari sistem anatomi di perut kelelawar yang saya andaikan terbelilit masa. Menggunakan bahan benang dan kawat yang tidak tegak lurus di ibaratkan sebagai perjalanan waktu yang nantinya dapat mematahkan waktu dengan sendirinya ynag artinya hewan ini dapat punah.

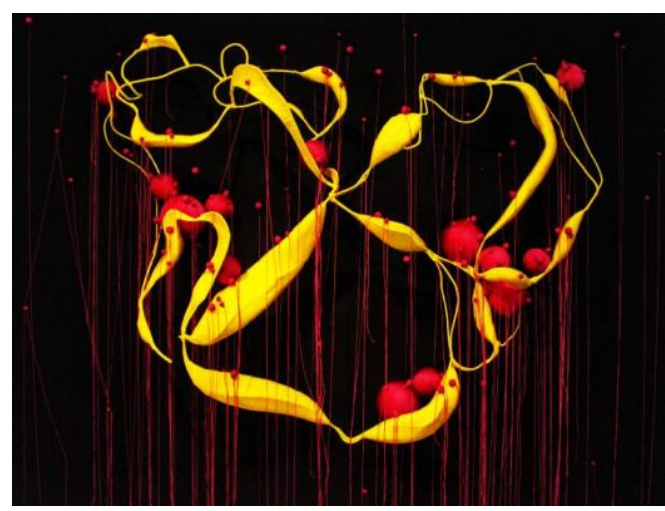

Gambar 4. Karya 2, Judul Karya "Hati yang Menangis",

Ukuran : $160 \mathrm{~cm} \times 120 \mathrm{~cm}$, Teknik: lilit.

Bahan : Benang Nilon Hank

(Foto : Arief Satriyo Wibowo, 2017)

Pada karya yang berjudul "Hati yang Menangis" ingin menegaskan bahwa sesungguhnya kita sebagai manusia harus mengerti atau peka terhadap lingkungan 
alam sekitar karena manusia sebagai mahluk yang di tuntut untuk hidup bersama. Bola bola merah berada di hati ini saya simbolkan dengan hewan kelelawar yang mana teringat akan hewan ini, selanjutnya dengan benang yang turun ke bawah menegaskan adanya kekecewaan. Hati yang menangis disini sebagai pemaknaan rasa empati terhadap kelangsungan hidup kelelawar akibat yang di timbulkan oleh manusia. Pengambilan warna yang diselipkan dengan simbol dan makna pada warna, pada background warna hitam menyimbolkan sesuatu yang negatif dalam karya ini negatifnya dimaksudkan terlukanya perasaan, pada warna kuning sekali lagi ditekankan dengan makna penghianatan, dan pada warna merah menyimbolkan kekerasan.

\section{PENUTUP}

Suatu karya seni lahir dan berawal dari pengamatan seniman terhadap lingkungan sekitar. Dari pengamatan tersebut timbul kegelisahan dalam diri seniman dan kegelisahan tersebut kemudian menjadi ide dan gagasan yang pada akhirnya tertuang dalam karya seni sebagai media curahan ekspresi dan imajinasi. Tiap-tiap seniman memiliki ciriciri karakter yang berbeda satu sama lain. Meski ide yang menjadi penciptaan sama namun karya yang diciptakan belum tentu sama karena setiap seniman memiliki pengalaman batin tersendiri.

Ide penciptaan karya seni tekstil ini berawal dari pengalaman pribadi, faktor alam, rasa simpati dan empati terhadap kelestarian fauna yaitu hewan kelelawar. Kesemua yang kemudian ditransformasikan ke bentuk karya non fungsional yang selanjutnya ingin membawa nilai-nilai perubahan sehingga khlayakan dapat mengetahuinya dan akhirnya dirasa mungkin dapat mengerti akan pesan yang disampaikan. Proses penciptaan karya pada non fungsional tehnik yang digunakan berupa lilit benang nilon hank di atas kawat. Dalam proses pembuatan karya seni tekstil ini di menemui beberapa kendala dalam pembuatan karya dimana proses perwujudan dari desain ke benda tiga dimensinya dalam segi pembuatan dan dalam teknik melakukan beberapa uji coba untuk menghasilkan hasil yang diinginkan mulai dari diameter kawat yang digunakan, dan perhitungan arah memulai benang.

\section{Daftar Pustaka}

Annas, Biranul. 2005. Seni dan Desain.

Bandung: ITB.

Budiman, Kris. 2011. Semiotika visual. Yogyakarta: Jalasutra.

Chapman, Laura H. 1978. Approaches to Art in Education. New York: Harcourt Brace Jovanovich.

Dharsono, Sony Kartika. 2004. Nanang Ganda Pratiwi, Pengantar Estetika, Rekayasa Sains, Bandung.

Feldman, Edmund Burke. 1967. Art, Image and Idea. Englewood Cliffs: Prentice Hall, Inc New Jersy.

Gustami SP. 2004. Proses Penciptaan Seni Kriya, Program Penciptaan Seni Paskasarjana. Institut Seni Indonesia Yogyakarta.

Gustami, Sp. 2007. Butir-Butir Mutiara Estetika Timur, Ide Dasar Penciptaan Karya. Yogyakarta: Prasistwa. 
160 ] CORAK Jurnal Seni Kriya Vol. 6 No.2, Nopember 2017-April 2018

Intsari. 1999. Sejarah Perkembangan Tekstil. Yogyakarta: Balai Besar Penelitian dan Pengembangan Industri Kerajinan dan Batik

Pitojo. 2005. Makanan yang Populer. Jakarta: Balai Pustaka

Soedarso SP. 2000. Katalogus Pameran Kriya Seni 2000. Jakarta: Galeri Nasional Indonesia. 